\title{
Properties of Adenyl Cyclase from Human Jejunal Mucosa during Naturally Acquired Cholera and Convalescence
}

\author{
Lincoln C. Chen, Jon E. Rohde, and Geoffrey W. G. Sharp \\ Pakistan-SEATO Cholera Research Laboratory, Dacca, East Pakistan, and \\ Departments of Medicine and Pharmacology, Massachusetts General \\ Hospital and Harvard Medical School, Boston, Massachusetts 02114
}

A в STRACT The enterotoxin of Vibrio cholerae causes copious fluid production throughout the length of the small intestine. As this is thought to be mediated by stimulation of adenyl cyclase, a study has been made of the activity and properties of this enzyme in jejunal biopsy tissue taken from patients during the diarrheal phase of cholera and after recovery. Adenyl cyclase activity during cholera was increased more than twofold relative to the enzyme in convalescence. Under both conditions stimulation by prostaglandin $\mathrm{E}_{1}\left(\mathrm{PGE}_{1}\right)$ and by fluoride was observed. The responsiveness to $\mathrm{PGE}_{1}$ was not altered in cholera; the total activity of the fluoride-stimulated enzyme was similar, a finding that suggests cholera toxin stimulates pre-existing enzyme in the intestinal cell. The enzymes during cholera and convalescence were similar in all other properties examined. Optimal $\mathrm{Mg}^{++}$concentration was $10 \mathrm{~mm} ; \mathrm{Mn}^{++}$ at $5 \mathrm{~mm}$ stimulated the enzyme but could not replace $\mathrm{Mg}^{++}$except in the presence of $10 \mathrm{~mm}$ fluoride. Calcium was markedly inhibitory at concentrations greater than $10^{-4} \mathrm{M}$. The $\mathrm{pH}$ optimum was 7.5 and the Michaelis constant $\left(K_{m}\right)$ for ATP concentration approximated $10^{-4} \mathrm{M}$. Thus the interaction of cholera toxin with human intestinal adenyl cyclase does not alter the basic properties of the enzyme. When biopsy specimens were maintained intact in oxygenated Ringer's solution at $0^{\circ} \mathrm{C}$, no loss of activity was observed at $1 \frac{1}{2}$ and $3 \mathrm{hr}$. In contrast, when the cells were homogenized, rapid loss of activity, with a half-life of $90 \mathrm{~min}$ was seen even at $0^{\circ} \mathrm{C}$. Consequently for comparative assays of human jejunal adenyl cyclase, strict control of the experimental conditions is required. It was under such

Dr. Sharp is supported by a Public Health Service Research Career Development Award (1 KO4 AM-42376) of the National Institute of Arthritis and Metabolic Diseases. Received for publication 19 August 1971 and in revised form 29 October 1971. conditions that a twofold increase in basal adenyl cyclase activity during cholera was observed.

\section{INTRODUCTION}

The massive acute diarrhea of cholera is caused by an enterotoxin elaborated by Vibrio cholerae (1). Studies in a variety of animal models show that cholera toxin causes net secretion of fluid and electrolytes resulting in luminal fluid accumulation $(2,3)$. This response to toxin challenge has not been found to be accompanied by histologic damage to intestinal epithelium $(4,5)$ and is unaffected by large changes of superior mesenteric blood flow (6). Intestinal glucose and substrate-dependent sodium transport remain intact $(7,8)$. These studies suggest, therefore, that the pathophysiology of cholera is due to an abnormality of ion transport in an otherwise functionally intact intestinal mucosa.

It is now thought that the mediator of toxin-induced fluid accumulation is an elevated concentration of intracellular adenosine-3',5'-cyclic monophosphate (cyclic AMP $)^{1}$ secondary to stimulation of adenyl cyclase. Enhanced adenyl cyclase activity and increased intracellular concentrations of cyclic AMP have been demonstrated in intestinal mucosa after toxin exposure (911). In addition agents which raise intracellular levels of cyclic AMP mimic the action of cholera toxin in vitro and in vivo (12-14).

With the aim of providing the biochemical foundation for exploration into the mechanism of cholera toxin interaction with adenyl cyclase and means of blocking the action of cholera toxin, we investigated the tissue preparation and properties of adenyl cyclase of human jejunal mucosa during naturally acquired disease and after recovery.

\footnotetext{
${ }^{1}$ Abbreviations used in this paper: cyclic AMP, adenosine$3^{\prime}, 5^{\prime}$-cyclic monophosphate; $K_{m}$, Michaelis constant; $\mathrm{PGE}_{\mathbf{1}}$ prostaglandin $\mathrm{E}_{1}$.
} 


\section{METHODS}

Patients. 45 adult patients with bacteriologically confirmed classical cholera, who were admitted to the Cholera Research Laboratory in Dacca, East Pakistan, were selected for study. Of the 45 patients, 24 were studied both during cholera and after recovery for paired analysis. All patients received routine i.v. therapy to correct volume depletion, electrolyte imbalance, and acidosis. Initial biopsies were performed within $24 \mathrm{hr}$ after onset of symptoms except for two patients who were biopsied 48 and $72 \mathrm{hr}$ after onset of diarrhea. Biopsies during convalescence were carried out no earlier than $24 \mathrm{hr}$ after complete cessation of diarrhea. $\mathrm{Pa}$ tients during initial biopsy were purging heavily with an average $24 \mathrm{hr}$ stool volume of 10.5 liters. Jejunal biopsies were performed using a Cooke capsule (15) with $4 \mathrm{~mm}$ aperture. All capsules were localized by X-ray to the first $20 \mathrm{~cm}$ of jejunum beyond the ligament of Treitz. After biopsy, daily hematocrits and stool guaiac tests were obtained, and no major complications from the biopsy procedure were noted.

Tissue preparation. The tissue was immediately placed in oxygenated phosphate Ringer's solution at $0^{\circ} \mathrm{C}$, washed in $75 \mathrm{~mm}$ Tris buffer ( $\mathrm{pH} \mathrm{7.5)}$ and $25 \mathrm{mM} \mathrm{MgCl}_{2}$ and homogenized by 10 strokes of a pestle in a TenBroeck glass hand homogenizer. Connective tissue was trapped between the wall of the homogenizer and the pestle, and the mixture above the pestle, which consisted of both broken and unbroken cells, was poured into a second homogenizer. 10 additional strokes completed homogenization of the mucosal cells. The protein concentration of the homogenate was estimated by the method of Lowry, Rosenbrough, Farr, and Randall (16), and diluted to a range of $20-50 \mu \mathrm{g} / 20 \mu \mathrm{l}$ for the assay, except for one study on the effects of varying protein concentrations on enzyme activity. In the paired studies, protein concentration in the assay mixture and time intervals between biopsy, homogenization, and incubation were matched for the cholera and convalescent studies.

Adenyl cyclase assay. Adenyl cyclase activity was determined by the method of Krishna, Weiss, and Brodie (17). Variables affecting tissue preparation and optimal enzyme activity were investigated in preliminary experiments and optimal assay conditions are described here. Duplicate samples of mucosal homogenate containing 20-50 $\mu \mathrm{g}$ protein/20 $\mu \mathrm{l}$ of Tris- $\mathrm{Mg}$ buffer were added to $30 \mu \mathrm{l}$ of incubation mixture containing $1 \mu \mathrm{Ci}$ ATP- $\alpha{ }^{32} \mathrm{P}$. Final composition of the incubation mixture was $30 \mathrm{~mm}$ Tris $(\mathrm{pH} 7.5), 10 \mathrm{~mm}$ $\mathrm{MgCl}_{2}, 0.1 \mathrm{~mm}$ cyclic AMP, $0.1 \mathrm{~mm}$ ATP, $5 \mathrm{~mm}$ phosphoenolpyruvate, $40 \mu \mathrm{g} / \mathrm{ml}$ phosphoenolpyruvate kinase and 20 $\mu \mathrm{g} / \mathrm{ml}$ myokinase. Reaction blanks for each set of experiments were estimated in the absence of homogenate. Each homogenate was also incubated in duplicate with $10 \mathrm{~mm}$ $\mathrm{NaF}$ to determine the maximal level of fluoride-stimulated activity.

To stop the reaction $1 \mathrm{ml}$ of a solution containing $50 \mu \mathrm{g}$ cyclic AMP, $100 \mu \mathrm{g} \mathrm{ATP}$, and $0.01 \mu \mathrm{Ci}$ cyclic $\mathrm{AMP}-{ }^{3} \mathrm{H}$ for calculation of recovery was added, and the reaction tubes were placed in boiling water for $5 \mathrm{~min}$. The contents of each assay tube were transferred to $0.6 \times 4.0 \mathrm{~cm}$ chromatographic columns of AG $50 \mathrm{~W}-\mathrm{X} 2$ (200-400 mesh) cation exchange resin. The cyclic AMP was eluted by water in the fourth and fifth milliliter. Remaining impurities in the eluant were removed by precipitation with $0.25 \mathrm{M} \mathrm{ZnSO}_{4}$ and $0.25 \mathrm{M}$ $\mathrm{Ba}(\mathrm{OH})_{2}$, care being taken that the final $\mathrm{pH}$ of the solution was close to 7.5. After centrifugation for $5 \mathrm{~min}$ at $2000 \mathrm{~g}$ the precipitation procedure was repeated. The supernatant was transferred to scintillation vials and ${ }^{8} \mathrm{H}$ and ${ }^{82} \mathrm{P}$ were estimated by double isotope counting in a Beckman LS-100 liquid scintillation counter (Beckman Instruments, Inc., Fullerton, Calif.). Recovery of cyclic AMP as determined by cyclic $\mathrm{AMP}-{ }^{3} \mathrm{H}$ varied from 50 to $70 \%$.

The results, expressed as pmoles of cyclic AMP produced per milligram of protein per $20 \mathrm{~min}$ were calculated from the specific activity of $\mathrm{ATP}^{32} \mathrm{P}$ in the incubation mixture and the total amount of cyclic $\mathrm{AMP}-{ }^{32} \mathrm{P}$ formed minus reaction blank. The total amount of cyclic AMP formed was the amount recovered corrected for loss during separation.

Materials. ATP $-\alpha^{32} \mathrm{P}(615 \mu \mathrm{Ci} / \mathrm{mmole})$ and cyclic AMP${ }^{3} \mathrm{H}$ (3 Ci/mmole) were obtained from the Radiochemical Centre, Amersham, England. Prostaglandin $\mathrm{E}_{1}\left(\mathrm{PGE}_{1}\right)$ was a gift from Dr. J. E. Pike of the Upjohn Co., Kalamazoo, Mich. Ion exchange resin AG 50 W-X2 (200-400 mesh) was purchased from Bio-Rad Laboratories, Richmond, Calif. Adenosine-5'-triphosphate disodium salt- $4 \mathrm{H}_{2} \mathrm{O}$, adenosine$3^{\prime}, 5^{\prime}$-cyclic phosphate- $\frac{1}{2}$ hydrate, 2-phosphoenolpyruvic acidtricyclo-hexammonium salt, pyruvate kinase from rabbit muscle $(300 \mathrm{IU} / \mathrm{ml}$ per $9.3 \mathrm{mg}$ protein) and myokinase from rabbit muscle $(660 \mathrm{IU} / \mathrm{mg}$ protein) were obtained from Calbiochem, Los Angeles, Calif. All other listed and unlisted chemicals were standard commercial preparations and were used without further purification.

Statistics. All $P$ values were obtained by paired analysis using Student's $t$ test.

\section{RESULTS}

\section{Adenyl cyclase activity}

Adenyl cyclase activity of jejunal mucosal homogenates was significantly elevated during acute cholera as compared with convalescent values. The results of 24 paired patient studies are shown in Fig. 1. The mean basal adenyl cyclase activity during cholera was $142.5 \mathrm{pmoles} / \mathrm{mg}$ per $20 \mathrm{~min}$ and $63.2 \mathrm{pmoles} / \mathrm{mg}$ per $20 \mathrm{~min}$ after recovery. All values obtained during cholera were above 74.5 and all recovery values below 83.0 except for one patient who had values of 139.0 and 174.5 for acute and convalescent phases, respectively. This patient was biopsied a third time two wk after recovery and still had a very high level of activity (165.3 pmoles/mg per $20 \mathrm{~min}$ ). The reason for this unusually high level of adenyl cyclase activity remains unknown. The effect of $10 \mathrm{~mm}$ sodium fluoride on 24 paired studies is also shown in Fig. 1. Fluoride was able to stimulate human intestinal adenyl cyclase, as has been found for all adenyl cyclases so far studied. It is of interest that the total activity measured during stimulation by fluoride was not significantly different between cholera-affected and convalescent tissues. This has been interpreted previously to indicate that cholera toxin does not induce synthesis of increased amounts of enzyme but rather stimulates pre-existing enzyme in the intestinal cells $(9,10)$.

\section{Enzyme characteristics}

The effect of different ATP concentrations in the reaction mixture. In Fig. 2 are shown the effects of 


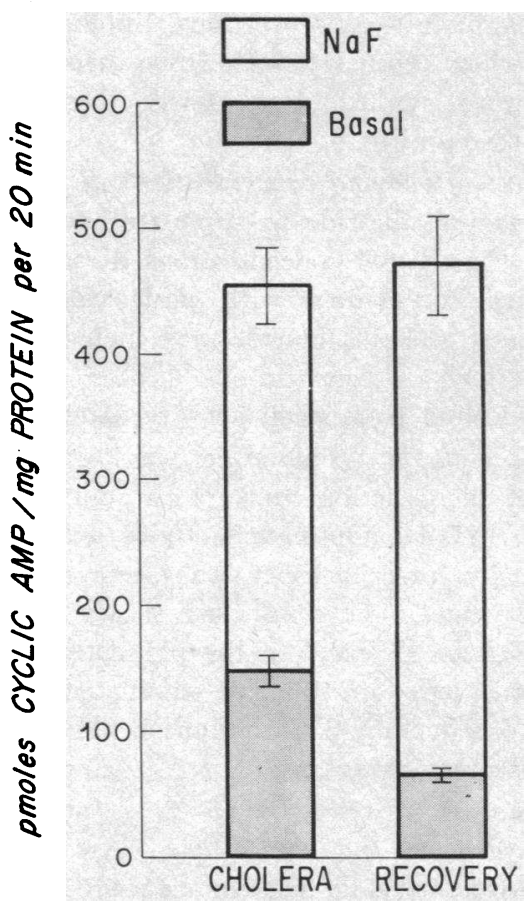

FIGURe 1 Adenyl cyclase activity of human jejunal mucosa in 24 paired patient studies during cholera and after recovery. Basal enzyme activity during cholera was increased more than twofold relative to the enzyme in convalescence $(P<$ 0.01 ). The total activity of fluoride-stimulated enzyme was similar from cholera to recovery. Brackets $= \pm$ SEM.

changes of ATP concentration on the rate of adenyl cyclase activity. The experiments were carried out on tissue from two cholera patients during the acute phase, one of the tissues being studied in the presence

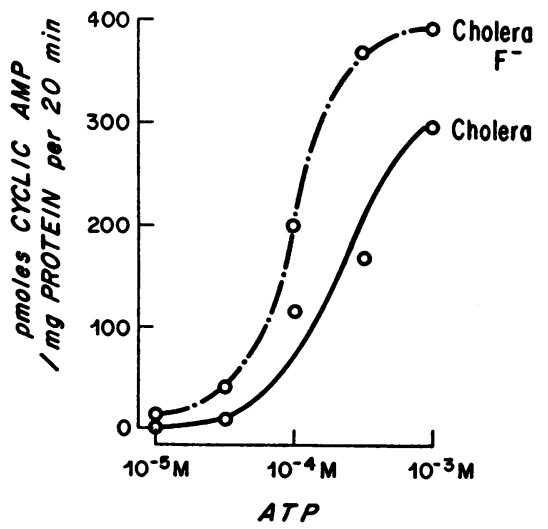

FIGURE 2 The effect of different ATP concentrations in the reaction mixture. The experiments were carried out on two patients during the acute phase of cholera, one of the tissues being studied in the presence of $10 \mathrm{~mm}$ fluoride. The rate of reaction appeared to be approaching saturation at $10^{-8} \mathrm{M}$ for the fluoride-stimulated state. Thus the $K_{m}$ is approximately $10^{-4} \mathrm{M}$. of $10 \mathrm{~mm}$ fluoride. Concentrations of ATP from $10^{-6} \mathrm{M}$ to $10^{-8} \mathrm{M}$ were tested. Due to the limited quantity of ATP- ${ }^{2} \mathrm{P}$ available to us in Pakistan, concentrations higher than $10^{-3} \mathrm{M}$ were not used. Consequently it was not possible to obtain an accurate Michaelis constant $\left(K_{\mathrm{m}}\right)$ for the substrate. However, the rate of reaction appeared to be approaching saturation at $10^{-8} \mathrm{M}$ for the fluoride-stimulated state. A $K_{\mathrm{m}}$ around $10^{-4} \mathrm{M}$ would appear to be correct. Little activity was observed with an ATP concentration of $10^{-5} \mathrm{M}$. All studies were subsequently performed with $10^{-4}$ M ATP in the reaction mixture, a course of action which permitted relatively high counts in cyclic AMP- ${ }^{22} \mathrm{P}$, low background counts and minimized breakdown of ATP- ${ }^{\star P}$ by ATPase. Thus the ATP-regenerating system of pyruvate kinase and myokinase maintained high ATP levels and permitted long reaction times.

The effect of $\mathrm{Mg}^{++}$and $\mathrm{Mn}^{++}$. Adenyl cyclase is a $\mathrm{Mg}^{++}$-dependent enzyme. Consequently, to optimize the assay conditions, the effects of different concentrations of $\mathrm{Mg}^{++}$from $5 \mathrm{~mm}$ to $50 \mathrm{~mm}$ were measured. The tests were performed under four different conditions using tissue from patients with cholera and during convalescence, in the presence and absence of $10 \mathrm{~mm}$ fluoride. It can be seen in Fig. 3 that very low levels

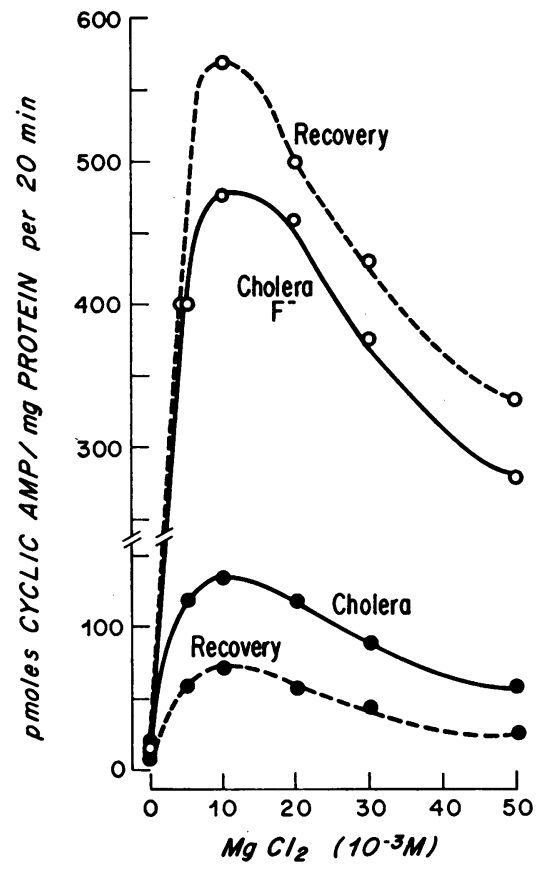

FIGURE 3 Stimulation of adenyl cyclase by magnesium. Results are means from three patients during cholera and two during convalescence. Magnesium markedly stimulated enzyme activity during cholera and after recovery. Optimal stimulation of both basal and fluoride activity was achieved at $10 \mathrm{~mm}$.

Jejunal Adenyl Cyclase in Human Cholera 
of activity were observed in the absence of added $\mathrm{Mg}^{++}$, but the activity increased sharply with $5 \mathrm{~mm}$ and reached peak values at $10 \mathrm{~mm} \mathrm{Mg}^{++}$. Higher concentrations were less effective, the rate of enzyme activity declining to low values at $50 \mathrm{~mm}$. $10 \mathrm{~mm} \mathrm{Mg}^{++}$was used in subsequent studies.

Manganese was not able to replace magnesium in the reaction mixture except in the presence of fluoride. In Fig. 4 is shown a comparison of the effects of $\mathrm{MgCl}_{2}$ and $\mathrm{MnCl}_{2}$ in concentrations up to $50 \mathrm{~mm}$. The tissues were from three patients with acute cholera. For basal enzyme activity $10 \mathrm{mM} \mathrm{MgCl}_{2}$ produced a maximal effect. With manganese chloride, however, only a slight stimulation occurred at $5 \mathrm{~mm}$ and this divalent cation was without effect at higher concentrations. In contrast to these results manganese was able to replace magnesium when the fluoride response was under study. $5 \mathrm{~mm}$ manganese chloride was as effective as 10 mM magnesium in stimulating the enzyme in the presence of $10 \mathrm{~mm}$ sodium fluoride. At concentrations of manganese above $5 \mathrm{~mm}$, the enzyme was progressively inhibited to a greater extent than was caused by in-

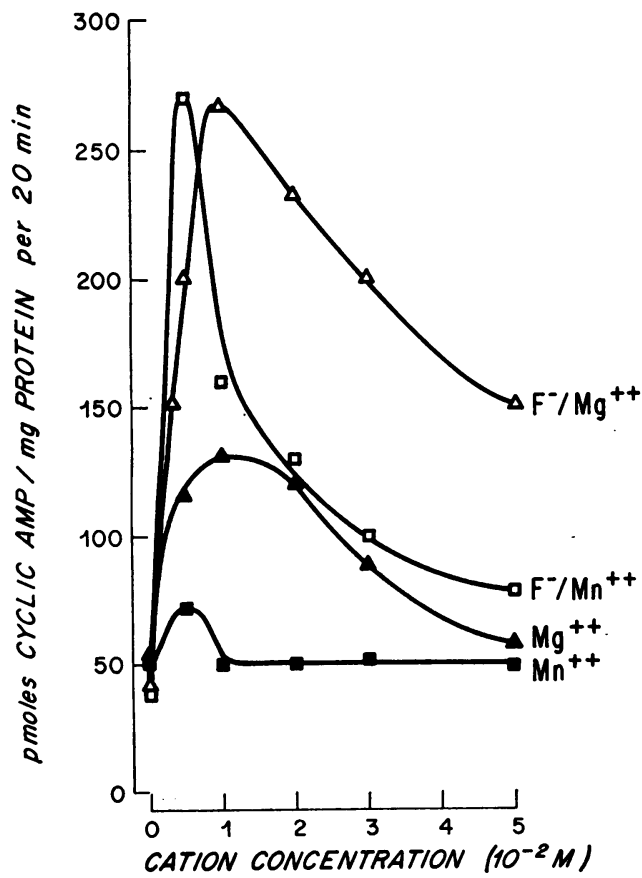

FIGURE 4 Effect of different concentrations of manganese and magnesium in the reaction mixture. The experiments were performed on tissues from three patients during acute cholera. Manganese failed to fully replace magnesium in stimulating basal activity. Minimal manganese stimulation at $5 \mathrm{~mm}$ was observed. For the fluoride-stimulated state, manganese at $5 \mathrm{~mm}$ was able to replace the optimal magnesium stimulation (magnesium $10 \mathrm{~mm}$ ). Three convalescent studies were also performed but similar results were obtained and for clarity these results are not interposed. creased magnesium concentrations. Similar results were obtained when jejunal tissues from three convalescent patients were studied. For clarity these results are not interposed on Fig. 4.

The effect of varying concentrations of fluoride. The effect of sodium fluoride to stimulate adenyl cyclase is shown in Fig. 5. All concentrations of sodium fluoride tested were stimulatory with peak values occurring when $10 \mathrm{~mm}$ sodium fluoride was included in the reaction mixture. Concentrations higher than $10 \mathrm{~mm}$ caused a decline from peak activity levels.

The effect of $p H$. This effect was tested by varying the $\mathrm{pH}$ of the reaction mixture in units of 0.5 from $\mathrm{pH} 6.5$ to $\mathrm{pH}$ 9.0. Optimum activity was seen at 7.5, and markedly lower activity was seen at both higher and lower values. The results are shown in Fig. 6. No differences were detected in the $\mathrm{pH}$ optimum for cholera, convalescent, or fluoride-stimulated enzyme activities. Consequently Tris buffer at $\mathrm{pH} 7.5$ was used for all subsequent assays.

Accumulation of cyclic AMP as a function of protein concentration and assay time. Assays were performed using varying protein concentrations in the reaction mixture from $10 \mu \mathrm{g}$ to $100 \mu \mathrm{g}$. For all tissues tested, the enzyme activity (when expressed per milligram of protein) was less when the protein concentration was below $20 \mu \mathrm{g}$ or above $50 \mu \mathrm{g} / 50 \mu \mathrm{l}$ incubation mixture than when it was between 20 and 50

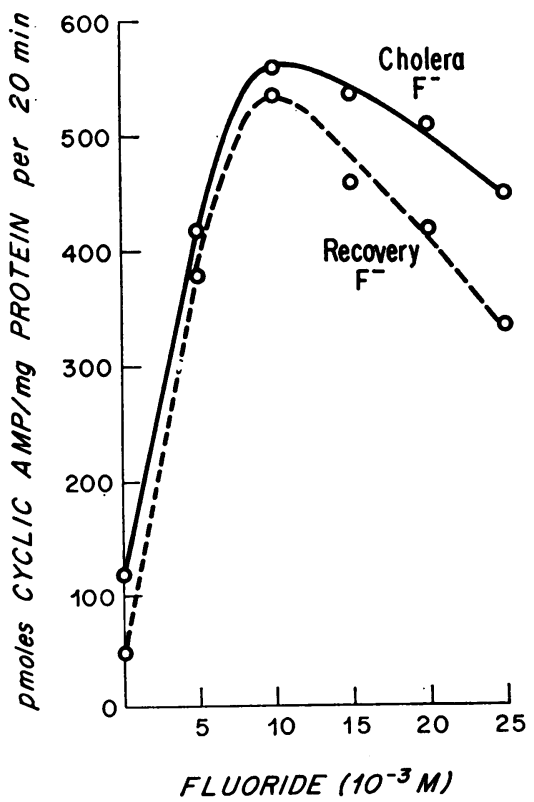

Figure 5 Effect of different concentrations of fluoride. Fluoride stimulated enzyme activity at all concentrations tested (5-25 mM). Optimal stimulation for both cholera and convalescent tissues was observed at $10 \mathrm{~mm}$ fluoride. 
$\mu \mathrm{g} / 50 \mu \mathrm{l}$. The reasons for these differences are not clear although the inhibitory effects of high protein concentrations have been noted previously (18). The reduced activity of low protein concentrations may be due to adsorption on the glass sides of the reaction tubes. It was necessary, therefore, to maintain all protein concentrations between 20 and $50 \mu \mathrm{g} / 50 \mu \mathrm{l}$. In Fig. 7 is shown the relationship between assay time and cyclic AMP production. Exact linearity with time is not achieved and a marked reduction of reaction rate appears between 20 and $30 \mathrm{~min}$. The reason for this is the rapid deterioration of the enzyme after homogenization, as shown in the next section.

Stability of the enzyme after homogenization. For studies on patients during acute cholera and convalescence, biopsies were taken several days apart. To compare the enzyme activities of the two tissues requires constant conditions of handling and assay. Consequently, the stability of the enzyme was studied, both in the intact tissue after biopsy and in the homogenate form. The results of the homogenate study are shown in Fig. 8. The homogenates from cholera and convalescent tissues were kept at $0^{\circ} \mathrm{C}$ in a salt-ice bath and adenyl cylase assayed at $60-\mathrm{min}$ intervals for $3 \mathrm{hr}$.

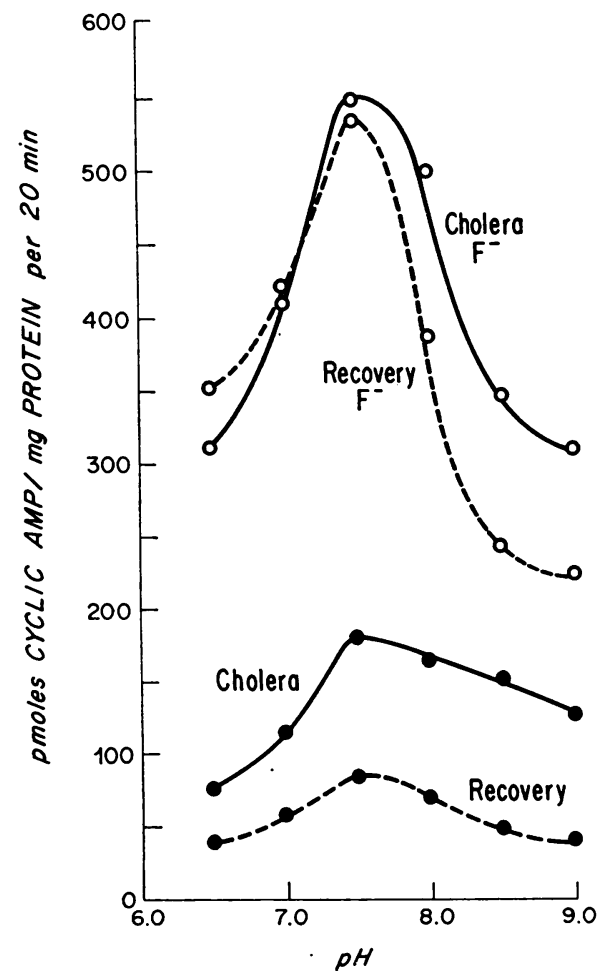

Figure 6 Effect of $\mathrm{pH}$. Enzyme activity at different $\mathrm{pH}$ from 6.5 to 9.0 was examined in three patients during cholera and convalescence. Optimal basal and fluoride activity was noted at 7.5 during cholera and after recovery.

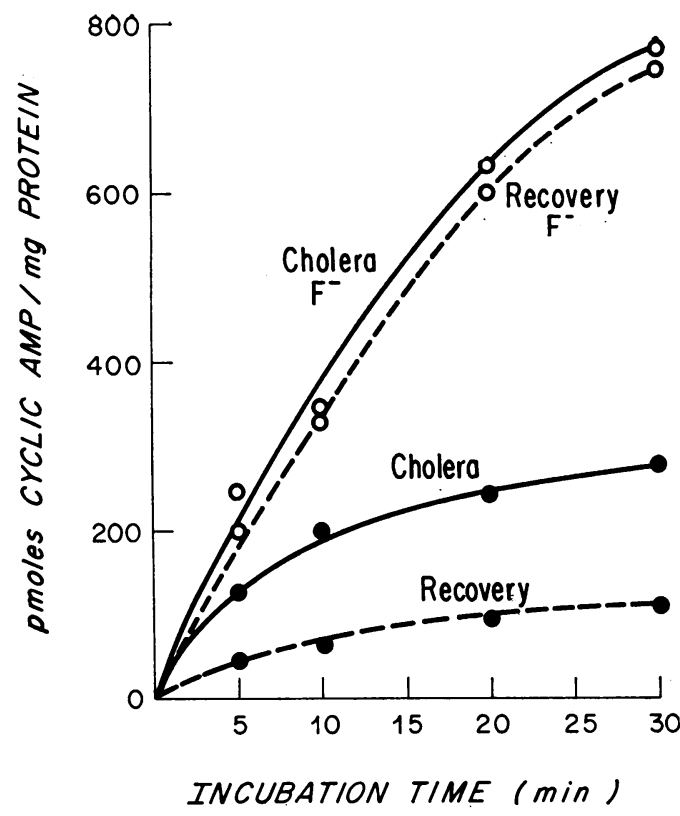

Figure 7 Accumulation of cyclic AMP as a function of incubation time. Three patients during cholera and convalescence were studied. Linearity was not achieved, with a marked decline in rate of reaction between 20 and $30 \mathrm{~min}$. Loss of linearity was due to the rapid decay of homogenate enzyme activity incubated at $37^{\circ} \mathrm{C}$.

Fluoride stimulation was also assessed. It is clear that the enzyme deteriorates rapidly with time even at $0^{\circ} \mathrm{C}$. The half-life for basal enzyme activity during cholera

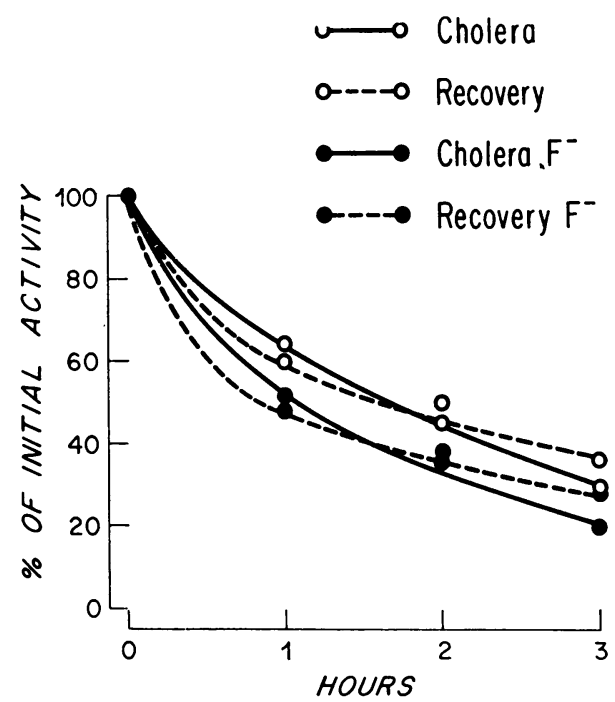

Figure 8 Stability of the enzyme after homogenization. Homogenates from three cholera and convalescent tissues showed rapid loss of basal and fluoride-stimulated activity when stored at $0^{\circ} \mathrm{C}$. Rate of decline did not differ from cholera to convalescence. Half-life was approximately 90 $\min$.

Jejunal Adenyl Cyclase in Human Cholera 


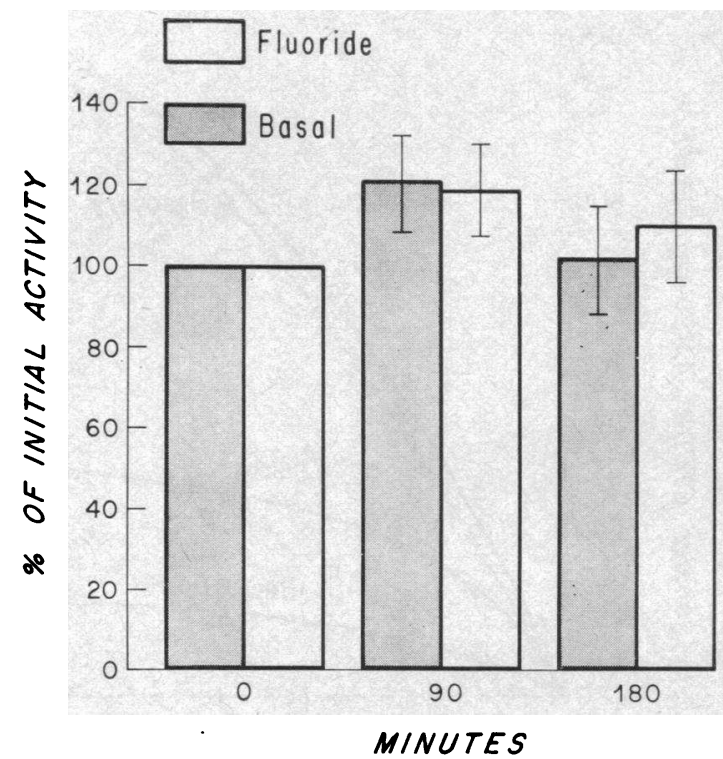

FIGURE 9 Stability of the enzyme in the intact biopsy tissue in three cholera and three convalescent patients. Intact biopsy samples stored at $0^{\circ} \mathrm{C}$ did not lose basal or fluoride stimulated activity for up to $3 \mathrm{hr}$. Brackets $= \pm 1$ SEM.

and convalescence and for the response to fluoride was between 1 and $1 \frac{1}{2} \mathrm{hr}$. Thus it is necessary to standardize exactly the time interval between homogenization and assay if one is to compare different tissues for adenyl cyclase activity. This was done for all the 24 paired patient studies reported in the first section of Results in this paper.

Stability of the enzyme in the intact tissue after biopsy. The second point of interest was the stability of the enzyme in the intact tissue after biopsy. For this study biopsy samples were divided into three pieces and placed in phosphate Ringer's solution at $0^{\circ} \mathrm{C}$. One piece was homogenized and assayed immediately and the other two were homogenized and assayed at 90 and

TABLE I

I Stability of Enzyme Activity of Intact Tissue Stored at $37^{\circ} \mathrm{C}$

\begin{tabular}{|c|c|c|c|c|}
\hline \multirow[b]{2}{*}{ Time } & \multicolumn{2}{|c|}{ Patient 1} & \multicolumn{2}{|c|}{ Patient 2} \\
\hline & Basal & Fluoride & Basal & Fluoride \\
\hline $\min$ & \multicolumn{4}{|c|}{ pmoles cyclic $A M P / m g$ protein per 20 min } \\
\hline 0 & 48.0 & 244.0 & 71.0 & 405.0 \\
\hline 90 & 14.5 & 112.5 & 50.0 & 332.0 \\
\hline 180 & 7.0 & 94.0 & 15.0 & 113.5 \\
\hline
\end{tabular}

Jejunal biopsy samples from two cholera patients during the diarrheal phase of the disease were stored in oxygenated buffered phosphate Ringer's solution ( $\mathrm{pH}$ 7.5). Marked decline of activity was noted in basal and fluoride stimulated activity at 90 and $180 \mathrm{~min}$.
180 min. In a similar study in two convalescent patients, the biopsy samples were kept at $37^{\circ} \mathrm{C}$ in oxygenated Ringer's solution and assays performed also at 0,90 , and $180 \mathrm{~min}$. The results of the $0^{\circ} \mathrm{C}$ study on six tissues (three cholera and three convalescent) are shown in Fig. 9. When the intact tissues were kept at $0^{\circ} \mathrm{C}$, no loss of adenyl cyclase activity occurred over 3 $\mathrm{hr}$. However, when the tissues were maintained at $37^{\circ} \mathrm{C}$ in oxygenated Ringer's solution a rapid loss of activity was observed (Table I). The rate of loss of basal enzyme activity was similar to that of the fluoride response, suggesting denaturation of the enzyme.

The effect of $\mathrm{Ca}^{++}$. The addition of calcium chloride to the reaction mixture was found to be inhibitory as shown in Fig. 10. Inhibition was apparent at $5 \times 10^{-4}$ $\mathbf{M}$ for basal activity in cholera and convalescent tissues. In the presence of fluoride calcium chloride was inhibitory at $1 \times 10^{-4} \mathrm{M}$. In all cases, at $5 \times 10^{-8} \mathrm{M}$ the inhibition was profound. This type of response is seen in most, though not all, adenyl cyclases studied thus far.

The effect of $P G E_{1}$. When $10^{-5}$ м PGE Pas added $_{1}$ was to the reaction mixture, a stimulation of adenyl cyclase activity was seen. The enzyme from cholera patients was stimulated from 146.9 to $173.8 \mathrm{pmoles} / \mathrm{mg}$ protein and from convalescent patients from 85.4 to 116.2 $\mathrm{pmoles} / \mathrm{mg}$ protein. The absolute increment in activity

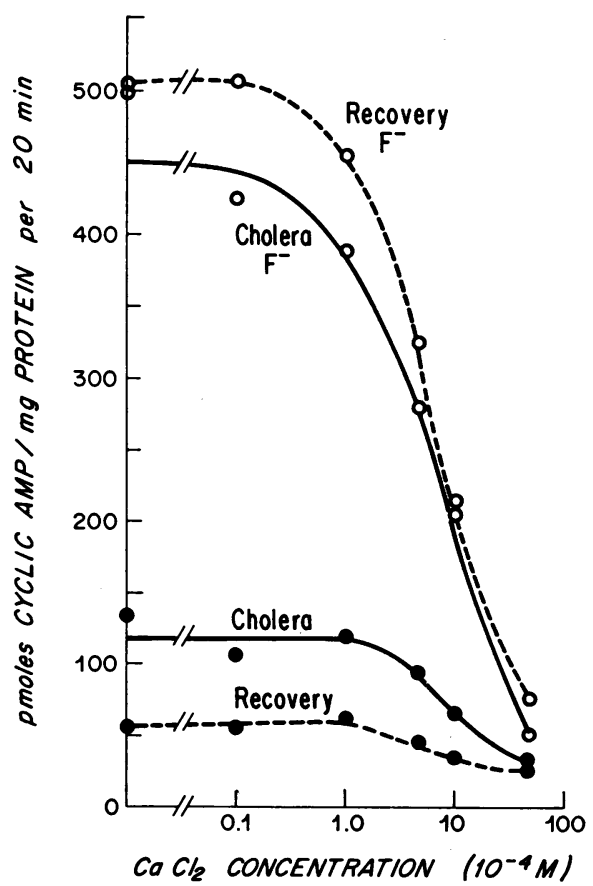

FIGURE 10 Inhibition of enzyme activity by calcium. In three cholera and convalescent patients calcium at concentrations greater than $1 \times 10^{-4}$ M markedly inhibited basal and fluoride-stimulated enzyme activity. 
TABLE II

Stimulation of Human Jejunal Adenyl Cyclase Activity by $P G E_{1}$

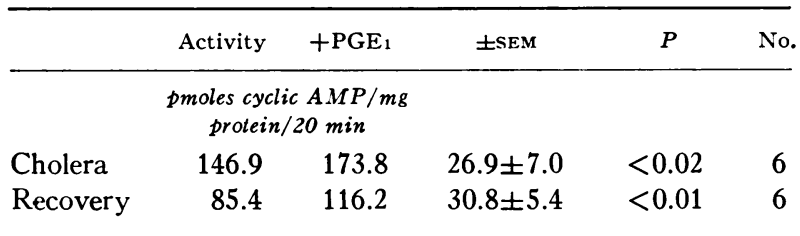

$\Delta$ increment due to $\mathrm{PGE}_{1}=-3.9 \pm 11.1(\Delta$ cholera $-\Delta$ recovery); $P=0.8$, No. $=6$. $\mathrm{PGE}_{1}$ at $10^{-5} \mathrm{M}$ stimulated enzyme activity in both cholera and convalescent tissues. The increment of $\mathrm{PGE}_{1}$ stimulation was not significantly different from cholera to convalescence.

due to $\mathrm{PGE}_{1}$ was not significantly different between cholera and convalescent studies. The results and levels of significance for six paired studies are shown in Table II.

\section{DISCUSSION}

The molecular mechanism by which cholera produces massive diarrhea is not known precisely. Normal intestinal net absorption of water and electrolytes is reversed during cholera to a net secretion along the length of the small intestine (2). The relative contribution of increased ion secretion and decreased ion absorption in the causation of fluid accumulation is still to be clarified. The fecal fluid is essentially isotonic, has raised bicarbonate and potassium relative to plasma and protein content is less than $250 \mathrm{mg} / 100 \mathrm{ml}$ (19). Physiological and histological studies have demonstrated intestinal impermeability to macromolecules such as polyvinylpyrrolidine (20) and an intact and apparently undamaged mucosa $(4,5)$.

A single cholera entero-exotoxin is thought to be entirely responsible for the disease. This toxin has recently been purified and is a protein with a molecular weight of about $80,000(21,22)$. It is both heat and acid labile. When exposed to the mucosal surface of intestinal epithelium, cholera toxin causes abnormal fluxes of water and electrolytes leading to luminal fluid accumulation and diarrhea (23). The action of this toxin is now thought to be mediated by cyclic AMP. Cyclic AMP and agents which raise cyclic AMP such as theophylline and prostaglandins mimic the action of cholera toxin on rabbit and human ileum in vitro (12, 13). Infusion of prostaglandins and theophylline into the superior mesenteric artery causes luminal fluid production which is similar to that produced by cholera toxin in experimental canine cholera (14). Mucosal cells of intestine have raised levels of cyclic AMP in association with cholera toxin-induced fluid production, and adenyl cyclase activity has been shown to increase in guinea pig and rabbit intestinal cells after toxin challenge $(9,10)$. Confirmation of these findings in humans has been presented in a preliminary report in which jejunal mucosal cells obtained by biopsy from cholera patients were found to have elevated adenyl cyclase activity relative to cells biopsied after recovery (24). The results of this paper extend the original observations and explore the properties of this enzyme.

Two lines of inquiry were important for the study of human intestinal adenyl cyclase. First, the optimal conditions for assay of the enzyme had to be determined. Second, it was necessary to find the correct conditions under which the activity of the enzyme could be compared when biopsy samples were obtained and assayed at intervals of several days. It is known that mammalian adenyl cyclase is a membrane-bound enzyme which required $\mathrm{Mg}^{++}$for the conversion of ATP to cyclic AMP. It is obvious that in any cell homogenate there are enzymes other than adenyl cyclase which will break down ATP, the major products being ADP and AMP. Thus an ATP regeneration system has been incorporated into most assays so that ATP concentrations are maintained at high levels throughout the incubation period. The optimum $\mathrm{Mg}^{++}$concentration for all conditions studied was found to be $10 \mathrm{~mm}$. Homogenates that contained between 20 and $50 \mu \mathrm{g}$ of protein/ $50 \mu \mathrm{l}$ gave optimal reaction rates. Although the concentration of ATP $\left(10^{-4} \mathrm{M}\right)$ employed did not give the maximal rate of cyclic AMP production, it had several advantages. For instance, it has been pointed out previously that with an ATP concentration of $10^{-4} \mathrm{M}$ one can obtain relatively high counts per minute in the assay sample without the use of prohibitively costly quantities of $\mathrm{ATP}_{-}{ }^{32} \mathrm{P}$. In addition the reaction blank has low counts and less breakdown of ATP by ATPase occurs which reduces the load on the regeneration system (25). To protect cyclic AMP- ${ }^{22} \mathrm{P}$ from destruction by phosphodiesterase, we have used $10^{-4} \mathrm{M}$ nonradioactive cyclic AMP in the reaction mixture. The use of theophylline for this purpose has the disadvantage that in some tissues theophylline inhibits adenyl cyclase activity in addition to its desired effect on phosphodiesterase (18).

Having defined the conditions of assay for the homogenate of jejunal mucosal cells, it was necessary to study the stability of the enzyme and conditions of assay under which tissue samples obtained several days apart could be compared. For instance, in this study the comparison of enzyme activity was required during the acute diarrheal stage of cholera and during the convalescent stage approximately $1 \mathrm{wk}$ later. The variables which concerned us most were the time intervals between biopsy, homogenization, and assay, and the proportionality of enzyme activity and protein con-

Jejunal Adenyl Cyclase in Human Cholera 737 
centration in the assay. From the results shown in Fig. 9 and Table $\mathrm{I}$ it was clear that the biopsy samples had to be cooled to $0^{\circ} \mathrm{C}$ as rapidly as possible and maintained at that temperature before homogenization. Rapid loss of enzyme activity occurred at $37^{\circ} \mathrm{C}$ even in oxygenated Ringer's solution (Table I). It is apparent however that providing the cells are kept intact at $0^{\circ} \mathrm{C}$, the activity remained constant for up to $3 \mathrm{hr}$. Under these conditions the time between biopsy and homogenization was not critical. This is in marked contrast to the situation after homogenization. Even at $0^{\circ} \mathrm{C}$ rapid loss of enzyme activity occurs; no differences in the rate of deterioration were seen between cholera and convalescence (Fig. 8). With a half-life of between 1 and $1 \frac{1}{2} \mathrm{hr}$ at this temperature, comparative assays of enzyme activity in samples taken on different days must be performed at exactly the same time after homogenization. Any variation in the time interval will necessarily falsify the comparison. Unfortunately we were unable to assay the samples immediately after homogenization, which would minimize breakdown, because of the need to match the protein concentration in the reaction mixture. It had been noted previously that proportionality of response between different concentrations of protein within the range of $20-50 \mu \mathrm{g} / 50 \mu \mathrm{l}$ was not obtained. Again, for comparative purposes, each assay on biopsies from different days had to be prepared with the same protein concentrations. Thus the homogenates from the first biopsy were assayed for protein content and diluted to the appropriate range for the assay. When the homogenate of the second biopsy was prepared, its protein content was determined and diluted to the same protein concentration as the first assay. Thus the intervals between biopsy, homogenization, and assay, and the protein concentrations were all maintained constant.

It was under these strictly standardized conditions of handling, assay and reaction mixture composition that the results shown in Fig. 1 were obtained. Adenyl cyclase activity was increased by $125 \%$ during the acute diarrheal phase relative to the activity during convalescence. The increased level of activity was highly significant and in only 2 patients out of the 24 were the adenyl cyclase activities not shown to be enhanced. No correlation of enzyme activity during cholera and magnitude of stool output were observed. This is not surprising since a variety of factors affected the absolute value of enzyme activity, the most important being the interval between homogenization and protein concentration. Recently, it has been demonstrated that stimulation of adenyl cyclase activity and net changes of water and sodium fluxes correlate with respect to time course and magnitude in experimental canine cholera."

Some properties of the enzyme during both cholera and convalescence were studied $(a)$ to see if differences exist which might be explored in the development of therapeutic agents and $(b)$ to see if any light could be shed on the mechanism of adenyl cyclase activation by cholera toxin. In the experiments discussed so far, except for the increase in basal enzyme activity, no differences have been seen in the characteristics of the enzyme obtained from patients with cholera or during convalescence. This applies to the requirements for ATP, $\mathrm{Mg}^{++}, \mathrm{pH}$, the concentration dependence of the fluoride response, stability, loss of activity after homogenization, and the effects of $\mathrm{Mn}^{++}, \mathrm{Ca}^{++}$, and $\mathrm{PGE}_{1}$.

When $\mathrm{Mn}^{++}$was used in the reaction mixture instead of $\mathrm{Mg}^{++}$, the basal activity was reduced at all concentrations tested between 5-50 mM. A slight stimulation at $5 \mathrm{~mm}$ was observed. When the fluoride response was studied, $5 \mathrm{~mm} \mathrm{Mn}{ }^{++}$was as effective as the optimal $\mathrm{Mg}^{++}$ concentration, namely $10 \mathrm{~mm}$. However, at higher concentrations the $\mathrm{Mn}^{++}$was inhibitory to a greater extent than high concentrations of $\mathrm{Mg}^{++}$. $\mathrm{Ca}^{++}$, when added to the reaction mixture (in the presence of $10 \mathrm{~mm} \mathrm{Mg}^{++}$), was found only to be inhibitory. No differences were observed between cholera and convalescent enzymes with respect to $\mathrm{Ca}^{++}$inhibition. The inhibitory effect was apparent at lower concentrations of $\mathrm{Ca}^{++}$when the fluoride response was studied than when the basal enzyme activity was under investigation.

Finally, the enzyme responsiveness to prostaglandin $\mathrm{E}_{1}$ was studied. $\mathrm{PGE}_{1}$ at a concentration of $10^{-5} \mathrm{M}$ stimulated both cholera and convalescent enzyme preparations. This is in agreement with reports of prostaglandin stimulation of adenyl cyclase in rabbit and guinea pig intestinal mucosa $(9,10)$. This study, however, also provides direct evidence that diarrheas associated with prostaglandins in man, such as those observed as a "side effect" of prostaglandin administration (26) or those associated with prostaglandin-secreting tumors $(27,28)$, may be mediated by stimulation of intestinal adenyl cyclase. During convalescence a stimulation of $30 \%$ was observed. In the acute stage the stimulation was $18 \%$. However, when the absolute increments in activity of the enzyme are compared they are similar, $26.9 \pm 7.0$ and $30.8 \pm 5.4$, respectively (Table II). Therefore the stimulation of $\mathrm{PGE}_{1}$ appears to be unaffected by the action of cholera toxin. This is contrary to a previous report that cholera toxin could enhance the response to $\mathrm{PGE}_{1}$ in rabbit intestine (9).

\footnotetext{
${ }^{2}$ Guerrant, R. L., L. C. Chen, and G. W. G. Sharp. Correlation of intestinal adenyl cyclase activity and changes of net water and sodium fluxes in experimental canine cholera. J. Infec. Dis. In press.
} 
This investigation on adenyl cyclase taken by biopsy from the patients in the acute diarrheal stage of cholera and during convalescence shows that the enzyme activity is enhanced by the disease process but that no other changes have been detected. Thus the mechanism by which cholera toxin interacts with adenyl cyclase does not alter the properties of this enzyme with respect to the parameters studied. Some features of the stimulation obtained in animal experimentation are of importance in this respect, with perhaps the four most relevant factors being $(a)$ that brief exposure of the intestinal mucosa to toxin results in a steady increase in the rate of fluid production (29) and concomitantly a steady increase in adenyl cyclase activity (9); (b) that there is a characteristic delay in the effects of cholera toxin on intestine and other tissues ${ }^{2}(30) ;(c)$ that when adenyl cyclase has been activated by the action of cholera toxin, the change is not reversed by washing the membranes containing this enzyme (31); and $(d)$ that the adenyl cyclase in the mucosal cells is in the basal and lateral membranes and not in the brush border (31). Therefore, the toxin exerts its action on the opposite side of the cells to which it is applied.

As a result of these studies, four lines of enquiry are currently being pursued: $(a)$ the possibility that the toxin is an enzyme-thus accounting for the progressive changes; $(b)$ that the toxin is broken down to smaller fragments before being active; $(c)$ the study of inhibitors of adenyl cyclase as potential therapeutic agents; (d) the possibility that the elevation of cyclic AMP is a general mechanism for the diarrhea of several disease states. In connection with the last point, a phospholipase $\mathrm{C}$ preparation which caused fluid accumulation and stimulation of adenyl cyclase (31) was derived from Clostridium welchii. $C$. welchii is also capable of causing both clinical (32) and experimental diarrhea (33), and phospholipase $\mathrm{C}$, or an impurity in the phospholipase $C$ preparation, could be a diarrheaproducing toxin accounting for the results. In addition, it has been reported that strains of enteropathogenic Escherichia coli are capable of producing an enterotoxin (34). This E. coli enterotoxin has been shown to enhance adenyl cyclase activity and cause ileal fluid production in rabbit intestinal loops (35). Like cholera toxin it also stimulates adenyl cyclase and lipolysis in rat fat cells. Therefore, at least three diarrheal diseases, those of cholera, clostridia, and E. coli, appear to be mediated by adenyl cyclase, and the cyclic AMP system may be a general mechanism for the production of other diarrheas. If this is so, one may presume the following potential mechanisms for the production of diarrhea: (a) stimulation of adenyl cyclase (either irreversibly as in cholera or transiently as with prostaglandins); (b) inhibition of phosphodiesterase; (c) potentiation of cyclic AMP-dependent protein kinase activity; and $(d)$ increase in activity of net body to lumen ion transport. Conversely, each of these steps is liable to pharmacological blockade.

\section{ACKNOWLEDGMENTS}

The authors gratefully acknowledge the technical assistance of Mr. Musa Hassan and Mr. Kamal Uddin. We also thank Miss Dorothy Torrance and the nursing staff of the Pakistan-SEATO Cholera Research Hospital for their excellent care of study patients.

The Pakistan-SEATO Cholera Research Laboratory is a part of the SEATO Cholera Research Program and is supported by the U. S. Agency for International Development, Department of State, The National Institutes of Health, and the Center for Disease Control of the Department of Health, Education, and Welfare, and by the Governments of Pakistan, the United Kingdom, and other SEATO countries. The N. I. H. Cholera Advisory Committee coordinates the research program. These studies were supported in part by research agreement No. 196802 between the National Institutes of Health, Bethesda, Md., and the PakistanSEATO Cholera Research Laboratory, Dacca, East Pakistan.

\section{REFERENCES}

1. De, S. N. 1959. Enterotoxicity of bacteria free culture filtrate of Vibrio cholerae. Nature (London). 183: 1533.

2. Carpenter, C. C. J., R. B. Sack, J. C. Feeley, and R. W. Steenburg. 1968. Site and characteristics of electrolyte loss and effect of intraluminal glucose in experimental canine cholera. J. Clin. Invest. 47: 1210.

3. Burrow, W., and G. Musteikis. 1966. Cholera infection and toxin in the rabbit ileal loop. J. Infec. Dis. 116: 183.

4. Gangarosa, F. T., W. R. Beisel, E. Benyajati, J. Sprinz, and P. Piyaratn. 1960. The nature of the gastrointestinal lesion in Asiatic cholera and its relation to pathogenesis: a biopsy study. Amer. J. Trop. Med. Hyg. 9: 125.

5. Elliot, H. L., C. C. J. Carpenter, R. B. Sack, and J. H. Yardley. 1968. Small bowel morphology in experimental canine cholera. A light and electron microscopic study. Amer. J. Pathol. 52: 15 a.

6. Carpenter, C. C. J., W. B. Greenough III, and R. B. Sack. 1969. The relationship of superior mesenteric artery blood flow to gut electrolyte loss in experimental cholera. J. Infec. Dis. 119: 182.

7. Sachar, D. B., J. O. Taylor, and J. R. Saha. 1969. Intestinal transmural electrical potential and its response to glucose in acute and convalescent cholera. Gastroenterology. 56: 512.

8. Hirschhorn, N., J. L. Kinzie, D. B. Sachar, R. S. Northrup, J. O. Taylor, Z. Ahmad, and R. A. Phillips. 1968. Decrease in net stool output in cholera during intestinal perfusion with glucose-containing solutions. $N$. Engl. J. Med. 279: 176.

9. Sharp, G. W. G., and S. Hynie. 1971. Stimulation of intestinal adenyl cyclase by cholera toxin. Nature (London). 229: 266 .

10. Kimberg, D. V., M. Field, J. Johnson, A. Henderson, and E. Gershon. 1971. Stimulation of intestinal mucosal adenyl cyclase by cholera enterotoxin and prostaglandins. J. Clin. Invest. 50: 1218.

Jejunal Adenyl Cyclase in Human Cholera 739 
11. Schafer, D. E., W. D. Lust, B. Sircar, and N. D. Goldberg. 1970. Elevation of adenosine- $3^{\prime}, 5^{\prime}$-cyclic monophosphate concentration in intestinal mucosa after treatment with cholera toxin. Proc. Nat. Acad. Sci. U.S. A. $67: 851$.

12. Field, M. 1971. Intestinal secretion: effect of cyclic AMP and its role in cholera. N. Engl. J. Med. 284: 1137.

13. Al-Awqati, Q., J. L. Cameron, M. Field, and W. B. Greenough III. 1970. Response of human ileal mucosa to choleragen and theophylline. J. Clin. Invest. 49: 2a.

14. Pierce, N. F., C. C. J. Carpenter, H. L. Elliot, and W. B. Greenough III. 1971. Effects of prostaglandins, theophylline, and cholera exotoxin upon transmucosal water and electrolyte movement in the canine jejunum. Gastroenterology. 60: 22.

15. Choudhury, D. C. R., G. I. Nicholson, and W. T. Cooke. 1964. Simple capsule for multiple intestinal biopsy specimens. Lancet. 2: 185

16. Lowry, O. H., N. J. Rosenbrough, A. L. Farr, and R. J. Randall. 1951. Protein measurement with the folin phenol reagent. J. Biol. Chem. 193: 265.

17. Krishna, G., B. Weiss, and B. B. Brodie. 1968. A simple sensitive method for the assay of adenyl cyclase. J. Pharmacol. Exp. Ther. 163: 379.

18. Hynie, S., and G. W. G. Sharp. 1971. Adenyl cyclase in the toad bladder. Biochim. Biophys. Acta. 230: 40.

19. Weaver, R. T., M. K. Johnson, and R. A. Phillips. 1948. Biochemical studies of cholera. J. Egypt. Public Health Ass. 23: 5.

20. Gordon, R. S. 1962. The failure of Asiatic cholera to give rise to "exudative enteropathy." Conf. Cholera Pap. Sum. Discuss. 1960. 54.

21. Finkelstein, R. A., and J. J. LoSpalluto. 1969. Pathogenesis of experimental cholera. Preparation and isolation of choleragen and choleragenoid. J. Exp. Med. $130: 185$.

22. Finkelstein, R. A., and J. J. LoSpalluto. 1970. Production of highly purified choleragen and choleragenoid. J. Infec. Dis. 121: S63.
23. Carpenter, C. C. J., and W. B. Greenough III. 1968. Response of the canine duodenum to intraluminal challenge with cholera exotoxin. J. Clin. Invest. 47: 2600.

24. Chen, L. C., J. E. Rohde, and G. W. G. Sharp. 1971 Intestinal adenyl cyclase in human cholera. Lancet. 1: 939 .

25. Bar, H. P., and O. Hechter. 1969. Adenyl cyclase assay in fat cell ghosts. Anal. Biochem. 29: 476.

26. Karim, S. 1971. Action of prostaglandins in the pregnant woman. Ann. N. Y. Acad. Sci. 180: 483.

27. William, E. D., S. M. M. Karim, and M. Sandler. 1968 Prostaglandin secretion by medullary carcinoma of the thyroid. A possible case of the associated diarrhea. Lancet. 1: 22.

28. Sandler, M., S. M. M. Karim, and E. D. Williams. 1968. Prostaglandins in aminepeptide-secreting tumors. Lancet. 2: 1053.

29. Pierce, N. F., W. B. Greenough III, and C. C. J. Carpenter. 1971. Vibrio cholerae enterotoxin and its mode of action. Bacteriol. Rev. 35: 1 .

30. Curlin, G. T., and L. C. Chen. 1971. Cholera toxin stimulation of rat lipocyte adenyl cyclase activity. Clin. Res. 19: 456. (Abstr.)

31. Sharp, G. W. G., S. Hynie, L. C. Lipson, and D. K. Parkinson. 1971. Action of cholera toxin to stimulate adenyl cyclase. Trans. Ass. Amer. Physicians Philadelphia. In press.

32. McNichol, M., and E. J. McKillop. 1958. Food poisoning caused by Clostridium welchii in cold chicken. Lancet. $1: 787$.

33. Duncan, C. L., and D. H. Strong. 1969. Experimental production of diarrhea in rabbits with Clostridium perfringens. Can. J. Microbiol. 15: 765.

34. Gyles, C. L., and D. A. Barnum. 1969. A heat-labile enterotoxin from strains of Escherichia coli enteropathogenic for pigs. J. Infec. Dis. 120: 419.

35. Evans, D. J., L. C. Chen, G. T. Curlin, and D. G. Evans. 1971. Adenyl cyclase: stimulation by Escherichia coli enterotoxin. Nature (London). In press. 